\title{
Corpos roubados
}

\author{
Raquel Vila Amado \\ Universidade de Santiago de Compostela \\ Instituto da Lingua Galega \\ raquel.vila.amado@usc.es
}

As primeiras xeracións de seres humanos, aqueles que foron quen de desenvolver o maior avance da nosa evolución, a creación da linguaxe articulada, tiveron a oportunidade de ser protagonistas dun momento apaixonante $\mathrm{e}$ que non se volverá repetir: poñerse nome a si mesmos e ós seres que os rodeaban, ós elementos e ós fenómenos da natureza, ás emocións, ós sentimentos... Ás cousas todas, visibles ou non, que conforman o mundo, a vida.

Non hai modo de saber cal sería a orde en que ese labor foi realizado. Seguramente en cada cultura ou comunidade as preferencias eran unhas, en función das súas necesidades ou dos seus intereses: a guerra, a caza, o grupo, a supervivencia, o concreto ou o abstracto. Pero non hai dúbida de que entre aquilo que primeiro se nomeou (no seu sentido primixenio de outorgarlle un nome) estaban as partes do corpo, aínda que só fose por curiosidade polo propio ou proximidade, por telas máis á man.

Por este motivo, por facer referencia ó que nós mesmos somos, o nome das partes do corpo constitúe un campo esencial (fulcral, dirían os clásicos) do léxico dun idioma. E o galego, como as demais linguas, desenvolveu unha inxente variedade de termos para aprehender o que o ser humano é no seu plano físico. A lista é tan extensa que se podería publicar un dicionario de galego dedicado só a falar das partes do corpo, cos seus sinónimos, as súas variantes dialectais e as súas formas cultas, populares, eufemísticas ou mesmo lúdicas: os nomes dos dedos, do maimiño ó cachapiollos, son unha mostra exquisita dese labor de creación colectiva. E falando de dedos, os nosos devanceiros decidiron que era máis operativo distinguir entre os das mans e os dos pés, de xeito que os galegos temos dedos e dedas, para que non se diga.

Pero os séculos de desprazamento que viviu o galego no seu propio ámbito deixaron a súa pegada tamén nesta parte, mediante a substitución dos termos de noso por outros tomados do castelán. Deste xeito, mesmo os falantes de galego menos contaminados por esta enxurrada de termos foráneos cambiaron os xeonllos por rodillas, os cóbados por codos, os nocellos por tobillos, os pulsos por muñecas. Non quedou unha soa articulación por desarticular.

Nisto talvez tivo máis culpa a Igrexa, coa súa teima de poñernos de rodillas; quizais foi máis cousa da escola, onde os nenos tiñan que sentar coa espalda recta e se castigaban cos nudillos as respostas erradas; se cadra do exército, co seu cuerpo a tierra!; ou mesmo de ben intencionados médicos e demais sandadores, que foron dando entrada ós novos vocábulos ó tempo que lles sacaban as muelas ós doentes e curaban con mel e bafos as gargantas acatarradas. Sexa como fose, o labor foi inexorable e eficacísimo e o corpus da lingua foise desmembrando paseniño. 
Así, os cadrís, o lomedro, as virillas, as coxas, as illargas, a ingua, as vidallas, a caluga, a sofraxe, o calcañar..., todo o que soase galego de máis foi desaparecendo da lingua en todos os seus niveis e ámbitos de uso. Deste estrago silencioso só se libraron as partes nas que a orixe latina común fixo que o seu nome coincidise ou se aproximase ó castelán (cabeza, ollos, brazos, pernas, pés...) ou aquelas zonas ás que, por pudor ou recato, a longa man das institucións castradoras non deu chegado.

A lingua é a maior obra colectiva dun pobo, a que máis e mellor nos representa ante nós mesmos e ante o mundo. E unha lingua na que a parte que empregamos para referírmonos a nós mesmos foi sistematicamente substituída polo léxico doutra está eivada na súa cerna. Non somos píntegas, nin augamares, nin gradicelas que recuperan os seus membros cando os perden: no noso caso, cada membro cernado fica perdido e nós ficamos tolleitos para sempre. Fóronnos roubando o corpo a anacos, parte por parte e palabra por palabra. Pero desta volta estamos a tempo de recuperalo, de sacalo da súa vaíña, antes de que o coman os vermes do esquecemento. 